\title{
A novel derivative of doxorubicin,AD 198, inhibits canine transitional cell carcinoma and osteosarcoma cells in vitro
}

This article was published in the following Dove Press journal:

Drug Design, Development and Therapy

25 September 2015

Number of times this article has been viewed

\section{Kusum Rathore Maria Cekanova \\ Department of Small Animal Clinical Sciences, College of Veterinary Medicine, The University of Tennessee, Knoxville, TN, USA}

\begin{abstract}
Doxorubicin (DOX) is one of the most commonly used chemotherapeutic treatments for a wide range of cancers. $N$-benzyladriamycin-14-valerate (AD198) is a lipophilic anthracycline that has been shown to target conventional and novel isoforms of protein kinase $\mathrm{C}$ (PKC) in cytoplasm of cells. Because of the adverse effects of DOX, including hair loss, nausea, vomiting, liver dysfunction, and cardiotoxicity, novel derivatives of DOX have been synthesized and validated. In this study, we evaluated the effects of DOX and its derivative, AD198, on cell viability of three canine transitional cell carcinoma (K9TCC) (K9TCC\#1-Lillie, K9TCC\#2-Dakota, K9TCC\#4-Molly) and three canine osteosarcoma (K9OSA) (K9OSA\#1-Zoe, K9OSA\#2-Nashville, K9OSA\#3-JJ) primary cancer cell lines. DOX and AD198 significantly inhibited cell proliferation in all tested K9TCC and K9OSA cell lines in a dose-dependent manner. AD198 inhibited cell viability of tested K9TCC and K9OSA cell lines more efficiently as compared to DOX at the same concentration using MTS (3-(4,5-dimethyl-2-yl)-5-(3-carboxymethoxyphenyl)-2-(4-sulfophenyl)-2htetrazolium) assay. $\mathrm{AD} 198$ had lower $\mathrm{IC}_{50}$ values as compared to DOX for all tested K9TCC and K9OSA cell lines. In addition, AD198 increased apoptosis in all tested K9TCC and K9OSA cell lines. AD198 increased the caspase activity in tested K9TCC and K9OSA cell lines, which was confirmed by caspase-3/7 assay, and cleavage of poly (ADP-ribose) polymerase (PARP) was confirmed by Western blotting analysis. In addition, AD198 cleaved PKC- $\delta$, which subsequently activated the p38 signaling pathway, resulting in the apoptosis of tested K9TCC and K9OSA cell lines. Inhibition of the p38 signaling pathway by SB203580 rescued DOX- and AD198-induced apoptosis in tested K9TCC and K9OSA cell lines. Our in vitro results suggest that AD198 might be considered as a new treatment option for K9TCC and K9OSA cell lines cancers in vivo.
\end{abstract}

Keywords: canine osteosarcoma, apoptosis, PKC- $\delta$, canine bladder cancer, chemotherapy

\section{Introduction}

Doxorubicin (DOX, Adriamycin) is an anthracycline antibiotic that intercalates to DNA molecules causing inhibition of the topoisomerase II enzyme ${ }^{1}$ during replication of DNA. DOX stabilizes the topoisomerase II and prevents the DNA double helix from being resealed, causing inhibition of replication ${ }^{2}$ with cytotoxic effects. ${ }^{3}$ DOX is one of the most commonly used chemotherapeutic treatments for a wide range of cancers, including leukemia, lymphoma, bladder, breast, stomach, lung, ovary, thyroid, soft tissue sarcomas, and multiple myeloma. ${ }^{3}$ DOX has been extensively used in treatments of bladder transitional cell carcinoma (TCC) ${ }^{4,5}$ and osteosarcoma (OSA). ${ }^{6,7}$ Patients treated with DOX might suffer adverse events, including hair loss, nausea, vomiting, liver dysfunction, and most importantly, cardiotoxicity. ${ }^{8,9}$

$N$-benzyladriamycin-14-valerate (AD198) is a structural congener of DOX. AD198 is a lipophilic anthracycline analog that is therapeutically superior to DOX in murine tumor 
systems $\mathrm{s}^{10}$ and has novel biochemical and pharmacological properties as compared to its parental compound DOX. ${ }^{11,12}$ DOX targets the nuclei of cells, blocks DNA synthesis through topoisomerase II inhibition, and increases generation of reactive oxygen species in cytoplasm of cells in order to induce apoptosis and inhibit cell growth. DOX increases the expression of P-glycoproteins (P-gp) that are associated with DOX-induced chemoresistance ${ }^{13}$ in treated cells. In contrast to DOX, AD198 targets protein kinase C (PKC) in cytoplasm of cells. ${ }^{14}$ The PKC family consists of 15 isozymes in humans; upon activation, PKC enzymes translocate to the plasma membrane and play a regulatory role in various cellular processes, including proliferation. ${ }^{15}$ AD198 has been shown to activate the PKC- $\delta$ pathway in HeLa cells. ${ }^{16,17}$ During apoptosis, PKC- $\delta$ is proteolytically cleaved by caspase- 3 and generates a constitutively activated catalytic fragment that amplifies apoptosis cascades in nucleus and mitochondria. ${ }^{18,19} \mathrm{PKC}-\delta$ has been shown to activate the p38 signaling pathway, which can also lead to apoptosis. ${ }^{20}$ Apoptosis is programed cell death where the caspase-cascade system plays an important role in the induction, transduction, and amplification of intracellular apoptotic signals. ${ }^{21}$ During apoptosis, one of the first proteins to be proteolyzed by caspase-3 is poly (ADP-ribose) polymerase (PARP), when the $116 \mathrm{kDa}$ form is cleaved to two fragments ( 89 and 24 $\mathrm{kDa}) .{ }^{22}$ The presence of cleaved PARP is generally considered as a marker of apoptosis. ${ }^{23}$ Two downstream targets of the p38 signaling pathway, cyclic AMP response element binding protein (CREB) and activating transcription factor 2 (ATF2), are transcription factors that also play an important role in apoptosis..$^{24,25}$

AD198 retains the anthraquinone/daunosamine sugar complex as DOX, yet the 14-O-valerate substitution along with the proximal ring adds the lipophilicity of AD198, which causes a rapid membrane penetration of AD198 to cells in contrast to DOX. This new lipophilic anthracycline AD198 circumvents multidrug resistance conferred by overexpression of multidrug transport proteins, such as P-gp. ${ }^{11} \mathrm{AD} 198$ is a non-cardiotoxic drug with cardioprotective effects through activation of the PKC- $\varepsilon$ pathway in cardiomyocytes, in contrast to DOX as shown in vivo in the rat model..$^{14}$ In fact, combination of low-dose AD198 along with DOX treatment has been shown to reduce cardiotoxicity of DOX in a rat model. ${ }^{10}$

Dogs diagnosed with spontaneous tumors offer unique models of human cancers to assist evaluation of new therapies for cancer treatments. ${ }^{26-30}$ Canine TCC (K9TCC) closely resembles human invasive urinary bladder cancer. ${ }^{31}$ Urinary bladder cancer is not very common in the dog, comprising only $<2 \%$ of all reported canine malignancies; $; 1,32$ however, almost $97 \%$ of all diagnosed bladder tumors are malignant. Dogs with OSA represent a unique model for human OSA due to similar histopathology, clinical presentation, and molecular targets, along with similar metastatic sites. ${ }^{33,34}$ Canine OSA (K9OSA) accounts for approximately $85 \%$ of primary bone cancers in the dog. It is a more common cancer in giant-breed dogs, and it occurs primarily in the appendicular skeleton. ${ }^{35}$

DOX has been used for treatment of $\mathrm{K} \mathrm{TCC}^{36}$ and $\mathrm{K} \mathrm{OSA}^{37}$ cancers. Similarly as in people, DOX has shown cardiotoxic effects in dogs, ${ }^{38}$ therefore there is a need for new therapeutic options for treatment of both cancers with reduced toxicity and adverse events. AD198 has shown potent antitumor activity using human and murine cell lines in vitro ${ }^{11,17,39-41}$ in TRAF3-deficient mouse B-lymphoma and human multiple myeloma cells transplanted into NOD SCID mice in vivo; ${ }^{42}$ however, AD198 has never been tested on K9TCC and K9OSA cell lines primary cancer cell lines in vitro.

In this study, we evaluated the effects of AD198 in three K9TCC (K9TCC\#2-Dakota, K9TCC\#1-Lillie, and K9TCC\#4-Molly) $)^{30,43}$ and three K9OSA (K9OSA\#1-Zoe, K9OSA\#2-Nashville, K9OSA\#3-JJ) primary cancer cell lines. We compared effects of AD198 and DOX and molecular mechanisms of their actions causing cell growth inhibition and apoptosis through the activation of PKC- $\delta$ and $\mathrm{p} 38$ signaling pathways in K9TCC and K9OSA cells in vitro.

\section{Methods}

\section{Antibodies and other reagents}

Antibodies for BAD, PKC- $\delta$, ATF2 (C-19), and actin were purchased from Santa Cruz Biotechnology Inc. (Dallas, TX, USA); antibodies for p-CREB and CREB were purchased from EMD Millipore (Billerica, MA, USA), and antibodies for PARP, p-p38, p38, and p-ATF2 was obtained from Cell Signaling (Boston, MA, USA). All other chemicals and reagents were purchased from Thermo Fisher Scientific (Waltham, MA, USA), unless otherwise specified. DOX was purchased from Sigma-Aldrich Co. (St Louis, MO, USA), p38 inhibitor SB203580 was purchased from Cell Signaling, and AD198 was a generous gift from Dr Leonard Lothstein from The University of Tennessee, Health Science Center in Memphis. Chemical structures of DOX and AD198 are shown in Figure 1A.

\section{K9TCC and K9OSA primary cancer cell lines}

Primary K9TCC (K9TCC\#1-Lillie, K9TCC\#2-Dakota, and K9TCC\#4-Molly) ${ }^{42,43}$ and K9OSA (K9OSA\#1-Zoe, K9OSA\#2-Nashville, K9OSA\#3-JJ) cell lines were isolated from tumor non-utilized portions of biopsy specimens 
A

DOX<smiles>COc1cccc2c1C(=O)c1c(O)c3c(c(O)c1C2=O)C[C@@](O)(C(=O)CO)C[C@H]3O[C@H]1C[C@H](N)[C@H](O)[C@@H](C)O1</smiles>

AD198

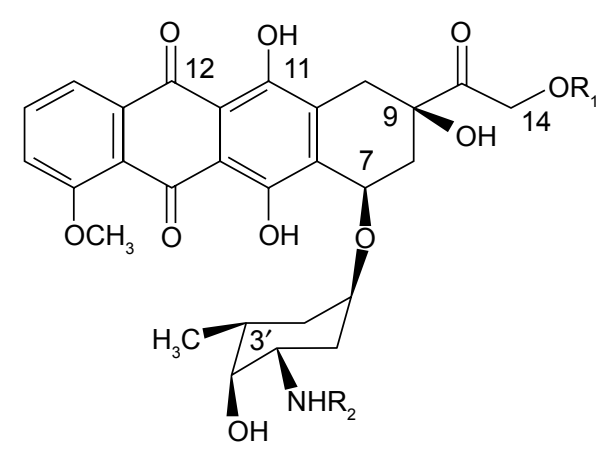

B

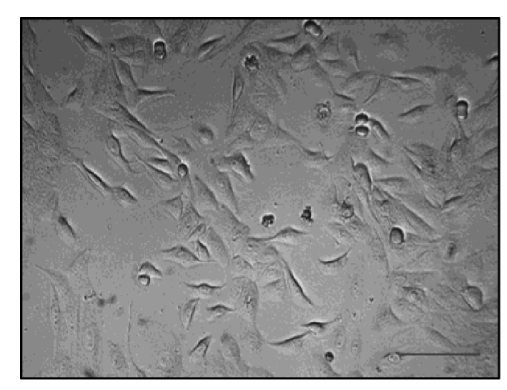

K9OSA\#1-Zoe

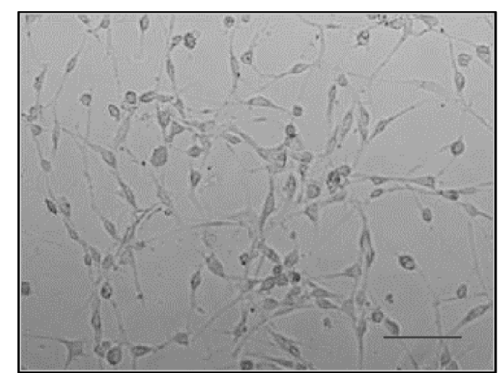

K9TCC\#2-Dakota

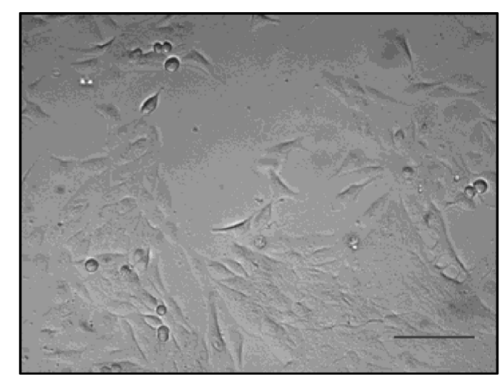

K9OSA\#2-Nashville

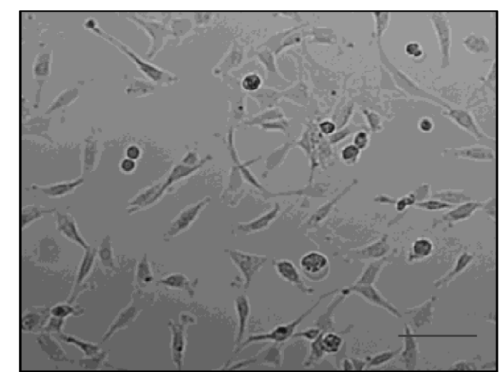

K9TCC\#4-Molly

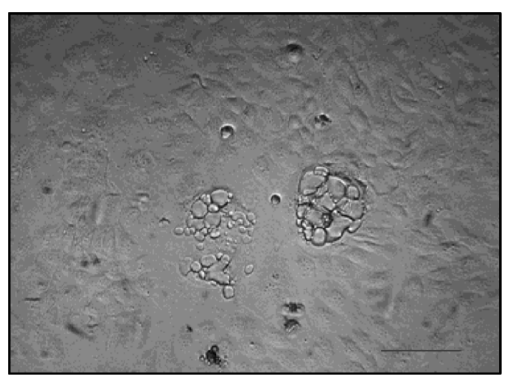

K9OSA\#3-JJ

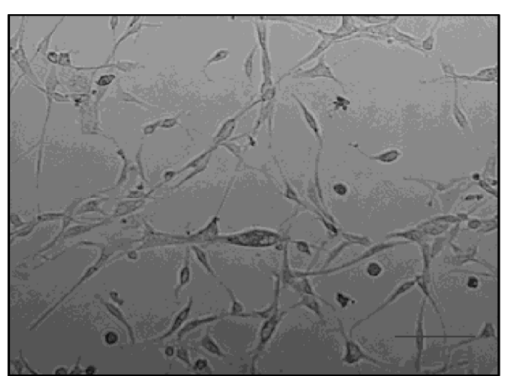

Figure I Morphology of tested K9TCC and K9OSA cell lines.

Notes: (A) Chemical structures of the DOX and N-benzyladriamycin-I4-valerate (ADI98) molecules. (B) Representative images of tested K9TCC\#I-Lillie, K9TCC\#2Dakota, K9TCC\#4-Molly, K9OSA\#I-Zoe, K9OSA\#2-Nashville, K9OSA\#3-JJ cells' morphology taken by a phase-contrast microscope. Objective 20× with scale bar 50 $\mu$ m. Abbreviations: DOX, doxorubicin; K9OSA, canine osteosarcoma; K9TCC, canine transitional cell carcinoma.

obtained from client-owned dogs diagnosed with bladder TCC or OSA; respectively, according to the approved procedure by the University of Tennessee (Knoxville, TN, USA) Institutional Animal Care and Use Committee (IACUC). The primary K9TCC cell lines are described in detail in our previously published studies. ${ }^{30,43}$ Briefly, the tumor biopsy tissues were washed and trypsinized, and separated cells were cultured in RPMI-1640 medium (K9TCC) or Dulbecco's Modified Eagle's Medium (DMEM) (K9OSA) with L-glutamine supplemented with 10\% fetal bovine serum, $100 \mathrm{IU}$ penicillin, and $100 \mu \mathrm{g} / \mathrm{mL}$ streptomycin in an atmosphere of $5 \% \mathrm{CO}_{2}$ at $37^{\circ} \mathrm{C}$ for 24 hours. Colonies of cancer cells identified under microscope were transferred into new culture dishes and expanded. K9TCC and K9OSA cell lines were progressed through at least three to five passages before using them in the experiments. All tested primary cell lines were maintained in culture for more than ten passages with no detectable changes in cell morphology (data not shown) with no detectable changes in behavior.

\section{Cell morphology of K9TCC and K9OSA cell lines}

All tested K9TCC and K9OSA cell lines were grown in RPMI1640 medium and DMEM, respectively. The morphology was examined under a phase-contrast microscope with $20 \times$ objective magnification (Vistavision; VWR Radnor, PA, USA) and images were captured using a Moticam camera (VWR) with Motic 5.0 software. 


\section{Cell proliferation assay (MTS)}

Cell proliferation (viability) was determined using the CellTiter96-Aqueous One Solution (MTS [3-(4,5-dimethyl-2-yl)-5-(3-carboxymethoxyphenyl)-2-(4-sulfophenyl)2h-tetrazolium]) cell proliferation assay (Promega Corporation, Fitchburg, WI, USA). Cells $\left(3 \times 10^{3}\right.$ cells/ well) were seeded in 96-well culture plates in four replicates and cultured for 24 hours, followed by the treatments with $0.1,0.5$, and $1 \mu \mathrm{M}$ DOX and AD198 for 48 hours. After DOX and AD198 treatment, the cells were incubated with MTS reagent following the manufacturer's protocol. The absorbance was measured at $490 \mathrm{~nm}$ using a plate reader (Bio-Tek Instruments, Inc., Winooski, VT, USA). The values for treatments were normalized to the control (DMSO-treated) group. $\mathrm{IC}_{50}$ values were calculated based on cell proliferation data using the online $\mathrm{IC}_{50}$ Tool Kit (http://www.ic50.tk/).

\section{Doubling time of K9OSA cells}

K9OSA cells were plated in triplicate in six-well plates. Cells were trypsinized and counted using a hemocytometer 24,48 , and 72 hours after plating. The doubling time for the cells was calculated using the following formula:

$$
\mathrm{dt}=\mathrm{t} \times \ln 2 / \ln (\mathrm{Ct} / \mathrm{Co})
$$

where $\mathrm{dt}$ is the doubling time, $\mathrm{t}$ is the time between cell counts $\mathrm{Ct}$ and $\mathrm{Co}, \mathrm{Co}$ is the initial count, $\mathrm{Ct}$ is the count after time $t$, and $\ln$ is natural $\log$. The doubling time of cells was expressed in hours.

\section{Apoptosis}

Apoptosis in K9TCC and K9OSA cell lines was detected using the TACS ${ }^{\circledR}$ Annexin V-FITC assay (Trevigen, Gaithersburg, MD, USA) according to the manufacturer's protocol. K9TCC and K9OSA cell lines $\left(1.5 \times 10^{6}\right.$ cells $)$ were grown in $10 \mathrm{~cm}$ petri dishes in complete media $(\mathrm{CM})$ for 24 hours. After plating the cells, the cells were treated with DOX $(1 \mu \mathrm{M})$ and AD198 $(1 \mu \mathrm{M})$ for 24 hours in serum-free media. After trypsinizing K9OSA and K9TCC cells, cells were washed with phosphate-buffered saline and incubated with annexin- $\mathrm{V}$ and propidium iodide solution at room temperature for 15 minutes. After washing with binding buffer, flow cytometry analysis was performed at the excitation and emission wavelengths of 488 and $550 \mathrm{~nm}$ for FITC conjugated annexin $V$ and 488 and $645 \mathrm{~nm}$ for propidium iodide measurements, respectively. Both subpopulations of annexinV-FITC-labeled cells and propidium iodide-labeled cells were validated to determine the percentage of cells undergoing apoptotic cell death using multi-cycle software (Phoenix, San
Diego, CA, USA). The values for treatments were normalized to control (DMSO-treated) group.

\section{Caspase- $3 / 7$ assay}

K9TCC and K9OSA cell lines $\left(1.5 \times 10^{6}\right.$ cells $)$ were grown in $10 \mathrm{~cm}$ petri dishes in complete media for 24 hours. After plating the cells, cells were treated with DOX $(1 \mu \mathrm{M})$ and AD198 $(1 \mu \mathrm{M})$ for 24 hours in serum-free media. After treatment, cells were lysed in ice-cold RIPA buffer as mentioned in the "Western blot analysis" section. Activities of caspases 3 and 7 were detected using the Caspase-Glo 3/7 Assay (Promega Corporation). Cell lysates containing $30 \mu \mathrm{g}$ of proteins were incubated with a proluminescent substrate specific for caspase-3/7 at a 1:1 ratio in a 96-well plate at room temperature for 1 hour. The luminescence values for each treatment were measured with a luminescence plate reader (Bio-Tek Instruments, Inc.) and normalized to control groups.

\section{Western blot analysis}

K9TCC and K9OSA cell lines $\left(1.5 \times 10^{6}\right.$ cells $)$ were grown in $10 \mathrm{~cm}$ petri dishes in $\mathrm{CM}$ for 24 hours, followed by treatment with DOX $(1 \mu \mathrm{M})$ and AD198 $(1 \mu \mathrm{M})$ for an additional 24 hours in serum-free media. After treatment, the cells were lysed in ice-cold RIPA buffer supplemented with protease and phosphatase inhibitors and kept at $-80^{\circ} \mathrm{C}$ until cell lysates were used for Western blot (WB) analysis as described previously in detail. ${ }^{30}$ Briefly, after blocking, the membranes were incubated with primary antibodies (PARP, PKC- $\delta$, p-p38, p38, p-ATF2, ATF2, p-CREB, CREB, and actin) at $4^{\circ} \mathrm{C}$ overnight and then incubated with horseradish peroxidaseconjugated secondary antibodies. Immunoreactive bands were visualized with an enhanced chemiluminescence system (Pierce Biotechnology, Rockford, IL, USA). The densitometry of protein expressions were normalized to actin from three independent WB experiments using ImageJ software (National Institutes of Health, Bethesda, MD, USA).

\section{Statistical analysis}

Statistical analyses were conducted using the paired Student's $t$-test to establish significant difference between various treatment groups. Results were considered statistically significant at $P<0.05, P<0.01$, and $P<0.001$.

\section{Results Morphology of K9TCC and K9OSA cell lines}

Primary K9TCC\#1-Lillie cell line was established from a tumor biopsy sample obtained from the urethra of a 
16-year-old female pointer dog. ${ }^{30}$ Primary K9TCC\#2-Dakota cell line was established from a tumor biopsy sample obtained from the urinary bladder of a 13-year-old female bichon frise dog. ${ }^{30,42}$ Primary K9TCC\#4-Molly cell line was established from a tumor biopsy sample of the urinary bladder of a 10-year-old female Maltese dog. ${ }^{30}$ Primary K9OSA\#1-Zoe cell line was established from a tumor biopsy sample obtained from a bone of a 5-year-old female Great Pyrenees dog. Primary K9OSA\#2-Nashville cell line was established from a tumor biopsy sample obtained from a bone of a 9-year-old female mixed-breed dog. Primary K9OSA\#3-JJ cell line was established from a tumor biopsy sample obtained from a bone of a 6-year-old female pit bull-boxer-mix dog.

To confirm cell origin of isolated cancer cells from tumors, the cytological smears (Figure 1B) of aspirated cells were stained by the Romanowsky staining protocol and confirmed by a pathologist (data not shown). The identified K9TCC had multinucleated cells and enlarged-size cells. The identified K9OSA cells had excessive vacuoles present in cytoplasm, which is one of the characteristics of OSA cells. The morphologies of tested K9TCC and K9OSA cell lines were evaluated with a phase-contrast microscope as shown in Figure 1B. Tested K9TCC cells had polygonal epithelial-cell morphology, except K9TCC\#4-Molly cells, which showed a more flattened appearance with vacuoles present in the cytoplasm of the cells. Tested K9OSA had flattened and elongated fibroblast-like morphology.

We evaluated the doubling time of K9OSA primary cancer cell lines, in addition to already reported doubling times of K9TCC. ${ }^{43}$ The values with doubling times of cells are presented in Table 1. The doubling time of the K9TCC cells ranged from 31.96 to 47.4 hours and that of K9OSA ranged from 42.86 to 46.1 hours, as shown in Table 1. The doubling times of K9TCC\#4-Molly and K9OSA\#3-JJ were 44.7 hours and 46.1 hours, respectively. The doubling times of tested K9TCC and K9OSA cell lines suggest that slow-growing cells might correlate with less aggressive tumors from which cells have been established.

Table I Doubling times for tested K9TCC and K9OSA cell lines

\begin{tabular}{ll}
\hline & $\begin{array}{l}\text { Doubling } \\
\text { time (h) }\end{array}$ \\
\hline K9TCC\#I-Lillie & $47.4^{43}$ \\
K9TCC\#2-Dakota & $32.0^{43}$ \\
K9TCC\#4-Molly & $44.7^{43}$ \\
K9OSA\#I-Zoe & 42.9 \\
K9OSA\#2-Nashville & 44.4 \\
K9OSA\#3-J & 46.1
\end{tabular}

Note: Doubling times of tested K9TCC and K9OSA cell lines were calculated based on cell proliferation measured 24,48 , and 72 hours after plating.

Abbreviations: h, hours; K9OSA, canine osteosarcoma; K9TCC, canine transitional cell carcinoma

\section{DOX and ADI 98 inhibited cell viability of all tested K9TCC and K9OSA cell lines}

AD198 targets PKC in nonnuclear cellular compartments ${ }^{14}$ and inhibits cell proliferation. Tested K9TCC and K9OSA cell lines were treated with $0.1,0.5$, and $1 \mu \mathrm{M}$ of DOX and AD198 for 48 hours, as shown in Figure 2. Both DOX and AD198 significantly reduced the proliferation of tested K9TCC (Figure 2A) and K9OSA (Figure 2B) cells. AD198 was significantly more effective in inhibition of cell viability of tested K9TCC and K9OSA cell lines as compared to DOX at the same concentration $(P<0.001)$ (Figure 2). $\mathrm{IC}_{50}$ values were calculated for DOX and AD198 for K9TCC\#1-Lillie, K9TCC\#2-Dakota, K9TCC\#4-Molly, K9OSA\#1-Zoe, K9OSA\#2-Nashville, K9OSA\#3-JJ, as shown in Table 2. The $\mathrm{IC}_{50}$ values for AD198 were lower than those for DOX in all tested cell lines. K9TCC\#4-Molly and K9OSA\#3-JJ cells were among the less responsive cells to therapy as compared to other cells, as shown in Figure 2 and Table 2 .

\section{DOX and ADI 98 induced apoptosis in K9TCC and K9OSA cell lines}

A representative cell line from each type of cancer was selected to further evaluate the molecular mechanisms of AD198 and DOX actions. We selected K9TCC\#2-Dakota and K9TCC\#1-Zoe cell lines to further evaluate the AD198and DOX-induced apoptosis based on chemosensitivity tests, as shown in Figure 2 and Table 2. DOX and AD198 both significantly increased apoptosis in tested K9TCC\#2-Dakota and K9OSA\#1-Zoe cell lines; furthermore, AD198 was more effective in inducing apoptosis than DOX treatment in both tested cell lines, as shown in Figure 3A. DOX and AD198 increased the caspase-3/7 activities, as shown in Figure 3B. AD198 was more effective in activating caspase-3/7 enzymes as compared to DOX in K9TCC\#2-Dakota and K9OSA\#1Zoe cells. In addition, increased cleavage of PARP by AD198 and DOX in both tested cell lines were confirmed (Figure 3C). Densitometry analysis of cleaved PARP protein showed an up to threefold increase in K9TCC\#2-Dakota and an up to fourfold increase in K9OSA\#1-Zoe when treated with AD198, as shown in Figure 3D. A statistically significant increase in PARP cleavage was observed after AD198 treatment as compared to DOX treatment in tested K9TCC and K9OSA cell lines.

\section{ADI 98 activated the PKC- $\delta$ signaling pathway in K9TCC and K9OSA cell lines}

To better understand the AD198- and DOX-induced apoptosis in K9TCC and K9OSA cell lines, we further investigated 

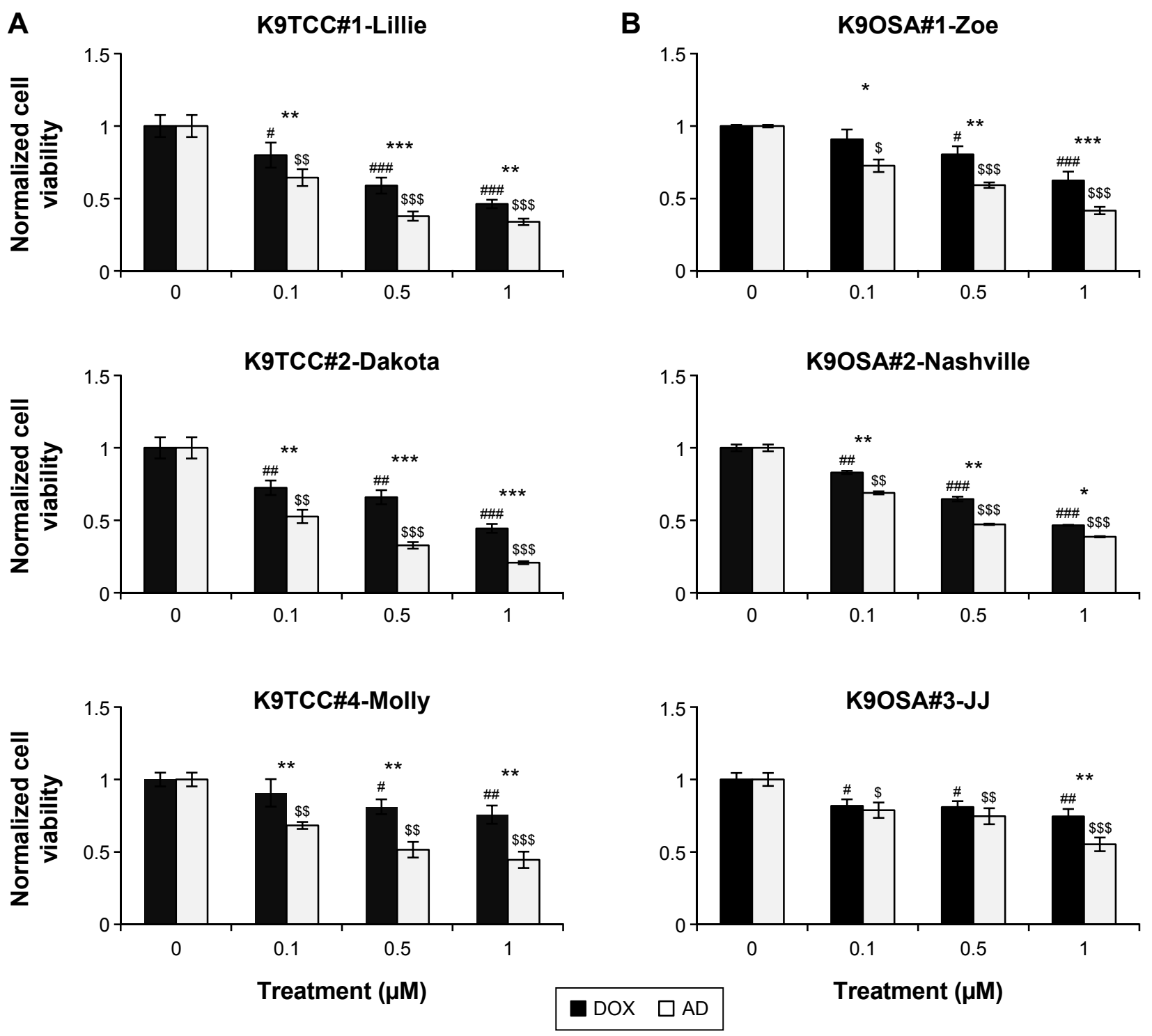

Figure 2 DOX- and ADI 98 (AD)-inhibited cell viability of tested K9TCC and K9OSA cell lines.

Notes: (A) K9TCC\#I-Lillie, K9TCC\#2-Dakota, and K9TCC\#4-Molly and (B) K9OSA\#I-Zoe, K9OSA\#2-Nashville, K9OSA\#3-JJ cells were treated with DOX (dark bars) and $A D$ (white bars) at $0,0.1,0.5$, and I $\mu \mathrm{M}$ for 48 hours and compared to control groups. Cell proliferation was determined by MTS assay and relative cell growth rate was normalized to control groups. Values represent mean \pm standard error $(n=16)$ of four replicates from four independent experiments. Paired Student's $t$-tests comparing DOX treatment to control ( ${ }^{\# P}<0.05,{ }^{\# P} P<0.01$, $\left.{ }^{\#} P<0.001\right)$, AD treatment to control $\left({ }^{\$} P<0.05,{ }^{\$ \$ P}<0.01\right.$, $\left.{ }^{\$ \$ \$ P}<0.001\right)$, and AD to $D O X$ treatment groups with the same dose treatment $(* P<0.05, * * P<0.01$, $* * * P<0.001)$ were used.

Abbreviations: AD, ADI98; DOX, doxorubicin; K9OSA, canine osteosarcoma; K9TCC, canine transitional cell carcinoma; MTS, 3-(4,5-dimethyl-2-yl)-5-(3carboxymethoxyphenyl)-2-(4-sulfophenyl)-2H-tetrazolium.

Table $2 \mathrm{IC}_{50}$ values of DOX and ADI98 of tested K9TCC and K9OSA cell lines

\begin{tabular}{lll}
\hline & DOX & ADI 98 \\
\hline K9TCC\#2-Dakota & $0.85 \mu \mathrm{M}$ & $0.42 \mu \mathrm{M}$ \\
K9TCC\#I-Lillie & $0.83 \mu \mathrm{M}$ & $0.56 \mu \mathrm{M}$ \\
K9TCC\#4-Molly & $2.07 \mu \mathrm{M}$ & $0.75 \mu \mathrm{M}$ \\
K9OSA\#I-Zoe & $1.36 \mu \mathrm{M}$ & $0.77 \mu \mathrm{M}$ \\
K9OSA\#2-Nashville & $0.88 \mu \mathrm{M}$ & $0.66 \mu \mathrm{M}$ \\
K9OSA\#3-JJ & $2.22 \mu \mathrm{M}$ & $1.13 \mu \mathrm{M}$ \\
\hline
\end{tabular}

Note: IC $C_{50}$ values of DOX and ADI 98 of tested K9TCC and K9OSA cell lines were calculated from cell proliferation data obtained from $0.1,0.5,1 \mu \mathrm{M}$ treatments with DOX and ADI 98 for 48 hours.

Abbreviations: DOX, doxorubicin; K9OSA, canine osteosarcoma; K9TCC, canine transitional cell carcinoma. the role of the PKC- $\delta$ signaling pathway. AD198 increased the cleavage of the PKC- $\delta$ in both tested K9TCC\#2-Dakota and K9OSA\#1-Zoe cell lines, as is shown in Figure 4A. A study has shown that activation of PKC- $\delta$ causes apoptosis through the activation of the $\mathrm{p} 38$ signaling pathway in human leukemia cells. ${ }^{20}$ Therefore, we tested the role of the p38 pathway in AD198-induced apoptosis. AD198 increased the phosphorylation of p38 more as compared to DOX in K9TCC\#2-Dakota and K9OSA\#1-Zoe cells (Figure 4A). Further, we studied the activation of downstream transcription factors of the $\mathrm{p} 38$ signaling pathway, such as p-CREB 
A

A

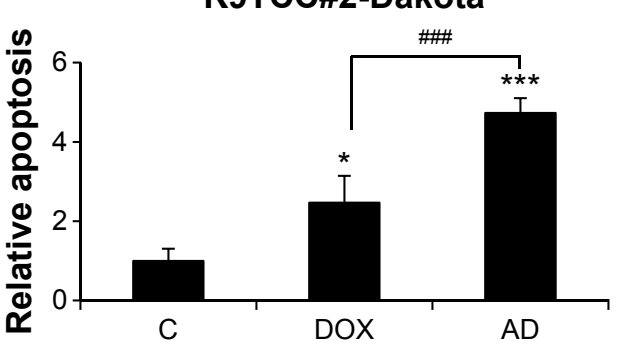

B

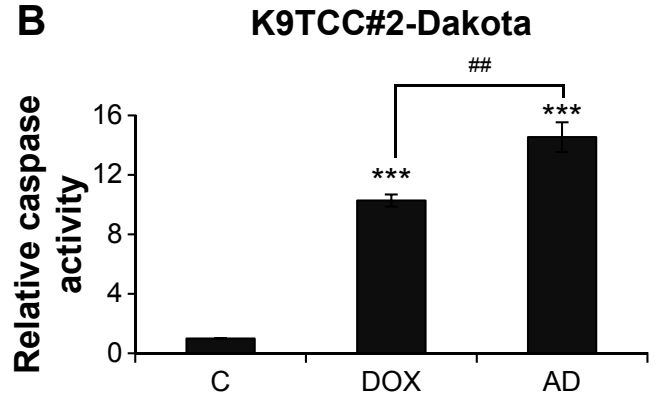

C K9TCC\#2-Dakota

C DOX AD

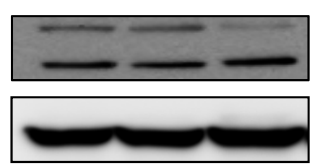

D

K9TCC\#2-Dakota PARP-cleaved fragment

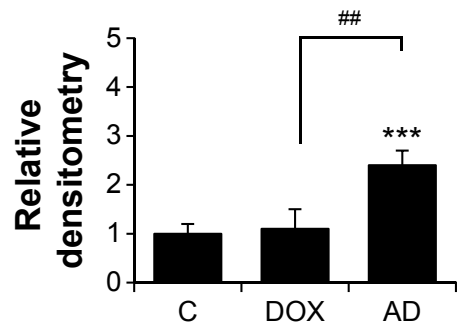

K9OSA\#1-Zoe

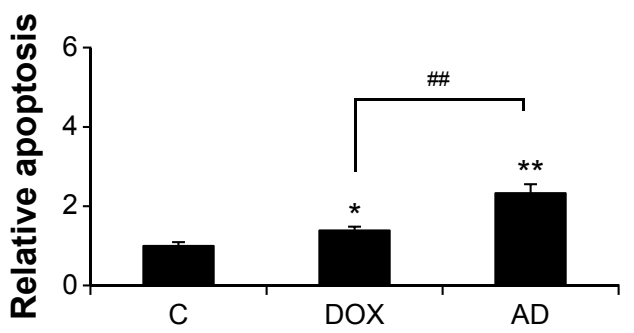

K9OSA\#1-Zoe

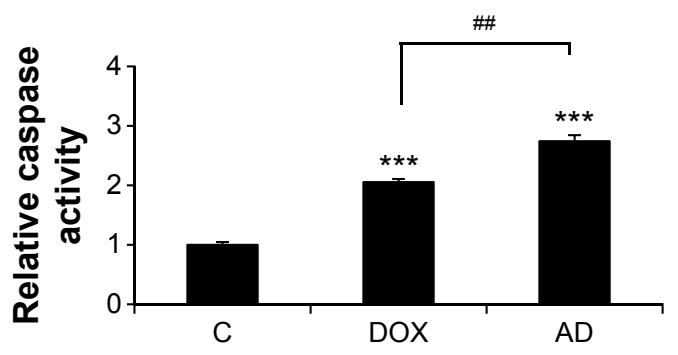

K9OSA\#1-Zoe

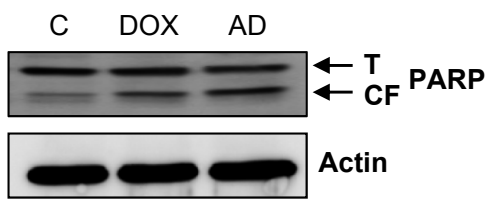

K9OSA\#1-Zoe

PARP-cleaved fragment

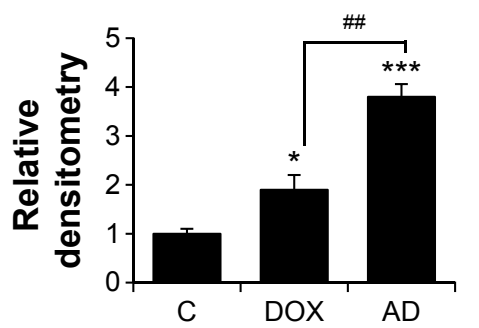

Figure 3 ADI 98 (AD)- and DOX-induced apoptosis and caspase activation in tested K9TCC and K9OSA cell lines in vitro.

Notes: (A) K9TCC\#2-Dakota and K9OSA\#I-Zoe cells were treated with I $\mu$ M DOX and I $\mu$ M AD for 24 hours and induced apoptosis was measured using the TACS Anexin V-FITC assay using a flow cytometer. Relative apoptotic activities were normalized to control groups. Values represent mean \pm standard error ( $=9$ ) of three replicates of three independent experiments. Paired Student's $t$-tests comparing treatment to control groups $(* P<0.05$, $* * P<0.0 \mathrm{I}$, $* * * P<0.00 \mathrm{I})$ and comparing among DOX and AD treatment groups $(\# P<0.01, \ldots P<0.00$ I) were used. (B) K9TCC\#2-Dakota and K9OSA\#I-Zoe cells were treated with I $\mu M$ DOX and I $\mu M$ AD for 24 hours and caspase activities were measured using the Caspase-Glo 3/7 luminescence assay. Relative caspase activities were normalized to control. Values represent mean \pm standard error $(n=6)$ of two replicates of three independent experiments. Paired Student's $t$-tests comparing treatment to control (***P<0.00I) and comparing among DOX and AD treatments ( $\# P<0.01$ ) were used. (C) K9TCC\#2-Dakota and K9OSA\#I-Zoe cells were treated with I $\mu M$ DOX and I $\mu M A D$ for 24 hours. The expressions of PARP(CF) were evaluated by WB analysis. Actin was used as loading control. The results are representative of three independent experiments ( $\mathrm{n}=3$ ). (D) Densitometry evaluation of PARP protein bands from WB analysis was done using Image software. Values represent the mean of measured densitometry of each protein's band from two replicates of three independent experiments \pm standard error $(n=6)$. Paired Student's $t$-tests were used to compare controls to DOX and AD treatments $(* P<0.05, * * * P<0.001)$ and to compare DOX to AD treatment $\left({ }^{\# P} P<0.01\right)$.

Abbreviations: AD, ADI98; PARP(CF), PARP-cleaved fragment; DOX, doxorubicin; K9OSA, canine osteosarcoma; K9TCC, canine transitional cell carcinoma; PARP, poly (ADP-ribose polymerase); PARP(T), total PARP; WB, Western blot.

and p-ATF2, CREB and ATF2, both of which were activated by AD198 in tested K9TCC\#2-Dakota and K9OSA\#1-Zoe cells (Figure 4A). No changes in the expression of total CREB were detected by AD198 or DOX treatments in tested canine cancer cells. Unfortunately, we did not detect any total ATF2 expressions using tested ATF2 antibodies due to antibodies not reacting with canine proteins (data not shown). Densitometry analysis of cleaved PKC- $\delta$, p-p38, p-ATF2, 
and $\mathrm{p}$-CREB protein expressions were normalized to actin in control and DOX- and AD198-treated cells, as shown in Figure 4B. Statistically significant increases of cleaved PKC- $\delta$, p-p38, p-ATF2, and p-CREB protein levels were observed in AD198-treated samples as compared to controls in both K9TCC\#2-Dakota and K9OSA\#1-Zoe cells.

To confirm the role of the p38 signaling pathway in AD198- and DOX-induced apoptosis, we co-treated cells with a p38 inhibitor, SB203580. The inhibition of the p38 signaling pathway by SB203580 rescued DOX- and AD198-induced apoptosis in tested K9TCC\#2-Dakota and K9OSA\#1-Zoe cell lines, as shown in Figure 5. SB203580 rescued DOX- and AD198-induced caspase-3/7 activity (Figure 5A), inhibited the production of cleaved PARP (Figure 5B and $\mathrm{C}$ ), and inhibited the phosphorylation of p-ATF2 and p-CREB (Figure 5D and E) in tested K9TCC and K9OSA cell lines.

AD198 increased apoptosis in K9TCC and K9OSA cell lines through the activation of PKC- $\delta$ and p38 signaling pathways. DOX and AD198 did not affect the other MAP kinases, such as ERK and AKT, in tested K9TCC\#2-Dakota and K9OSA\#1-Zoe cells (data not shown).

\section{Discussion}

Spontaneously occurring cancers in companion animals are more similar to human malignancies as compared to the chemically or genetically induced tumor mouse models. ${ }^{44}$ As in humans, spontaneous carcinomas in dogs are influenced by age and environmental factors. ${ }^{45}$ Current treatment for OSA in humans includes chemotherapeutic drugs, including DOX, methotrexate, cisplatin, ifosfamide, and etoposide, by themselves or in a combination regimen. ${ }^{7}$ Other treatment options for OSA include PEGylated interferon-alpha, ${ }^{46}$ small-molecule kinase inhibitors that inhibit serine/threonine kinases, ${ }^{47}$ and bisphosphonates. ${ }^{48}$ The most common treatments of OSA in dogs include limb amputation and chemotherapy including DOX, with $50 \%$ surviving 1 year and $20 \%$ of dogs surviving 2 years or longer. ${ }^{44}$ Treatment options for TCC include chemotherapeutic mitomycin into the bladder ${ }^{49}$ and immunotherapy using infusions of Bacillus Calmette-Guérin, ${ }^{50}$ and chemotherapy for TCC consists of the GC regimen (gemcitabine and cisplatin) or MVAC regimen (methotrexate, vinblastine, Adriamycin/DOX, and cisplatin). ${ }^{51}$ In dogs, combination protocols using chemotherapy and the nonsteroidal antiinflammatory drugs are the most promising treatment options for TCC. Surgery and radiation therapy are useful treatment modalities in select cases. ${ }^{52}$

In this study, we evaluated the mechanisms of DOX and its derivative, AD198, actions in three K9TCC and three K9OSA cells in vitro. AD198, as a structural congener of DOX, has shown to be non-cardiotoxic in contrast to DOX in a rodent model in vivo. ${ }^{10}$ AD198 has been shown
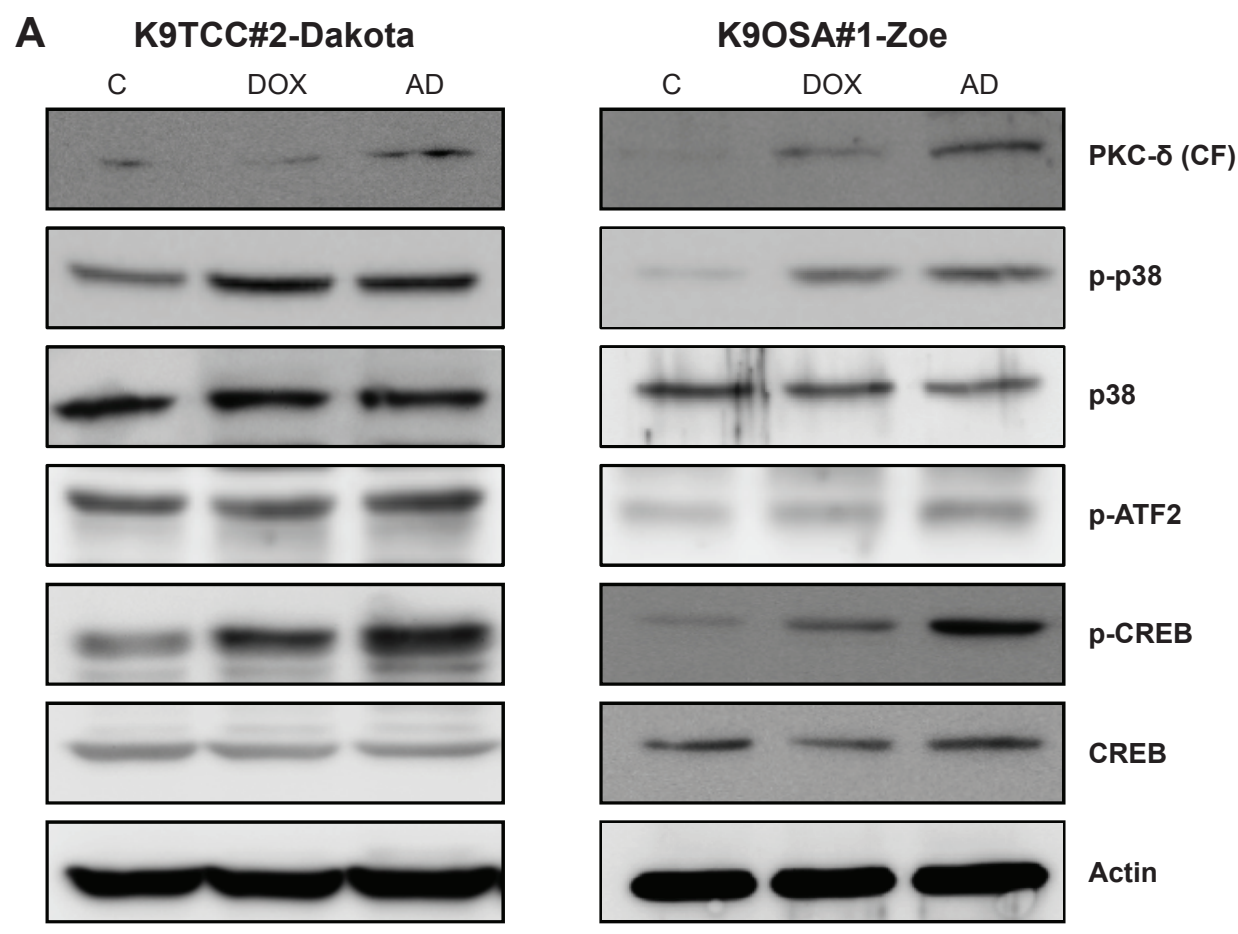

Figure 4 (Continued) 
B

K9TCC\#2-Dakota

PKC-ठ (CF)
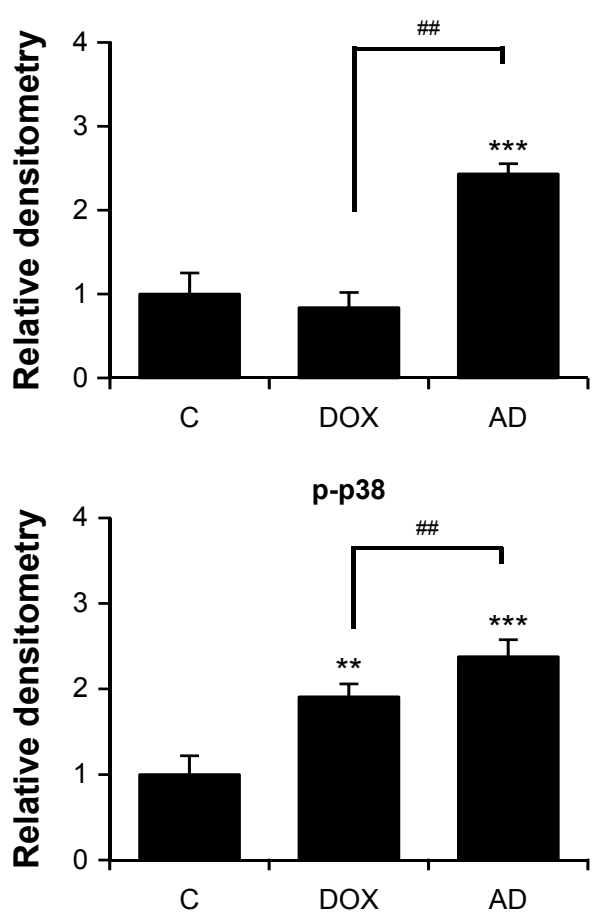

p-ATF2

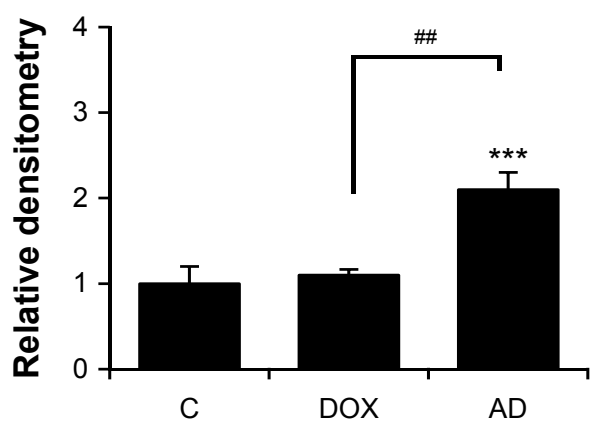

p-CREB

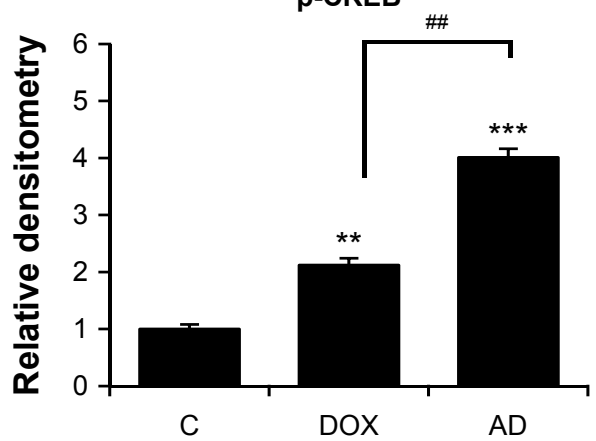

K9OSA\#1-Zoe

PKC-ठ (CF)
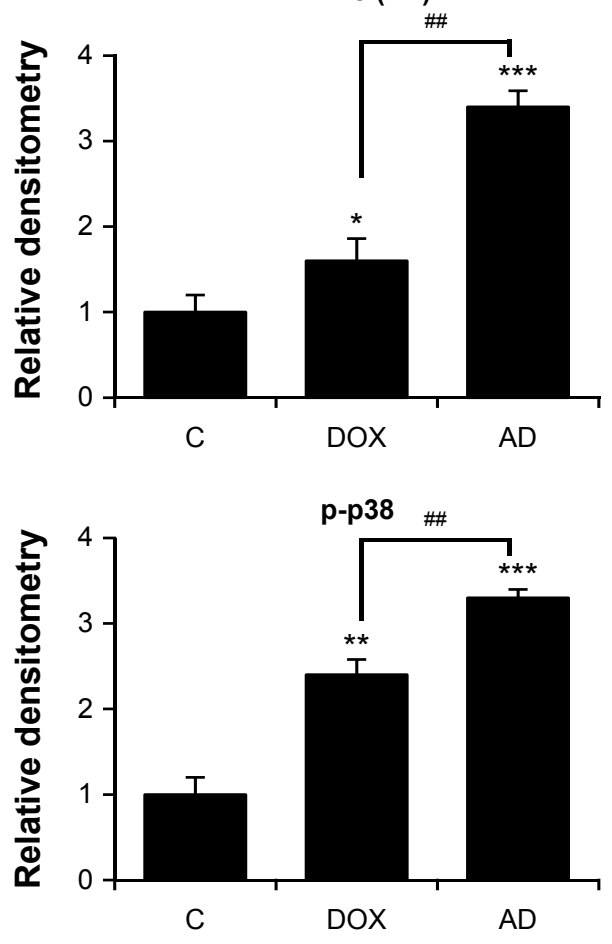

p-ATF2 \#

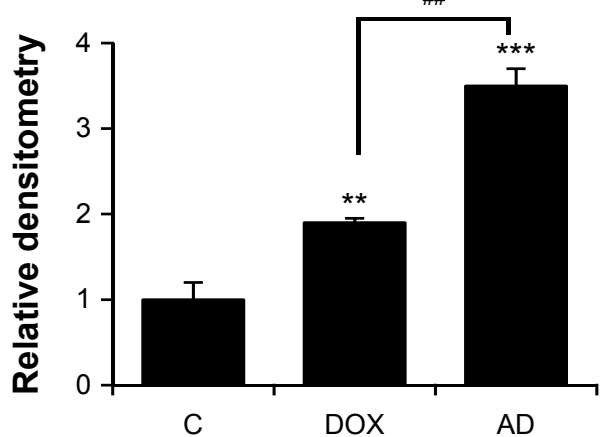

p-CREB

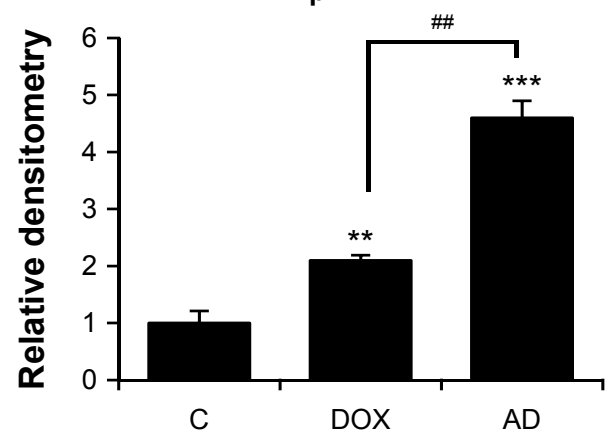

Figure 4 ADI 98 (AD) and DOX activated the PKC- $\delta$ pathway in tested K9TCC and K9OSA cell lines.

Notes: K9TCC\#2-Dakota and K9OSA\#I-Zoe cells were treated with I $\mu$ M DOX and I $\mu$ M AD for 24 hours. (A) CREB, PKC- $\delta$ (CF), P-p38, p38, p-CREB, p-ATF2, and CREB protein levels were detected by WBs. Actin was used as loading control. The results are representative of three independent experiments ( $n=3)$. (B) Densitometry evaluation of PKC- $\delta$ (CF), p-p38, p-ATF2, and p-CREB protein bands from WB analysis was done using Imagej software. Values represent the mean of measured densitometry of each protein's band from two replicates of three independent experiments \pm standard error $(n=6)$. Paired Student's $t$-tests were used to compare controls to DOX and AD treatments $(* P<0.05, * * P<0.01$, $* * * P<0.001)$ and to compare $D O X$ to $A D$ treatment $(\# P<0.01)$.

Abbreviations: AD, ADI98; ATF2, activating transcription factor 2; PCK- $\delta$ (CF), cleaved fragment of PKC- $\delta$; CREB, cyclic AMP response element binding protein; DOX, doxorubicin; K9OSA, canine osteosarcoma; K9TCC, canine transitional cell carcinoma; PKC- $\delta$, protein kinase C-delta; WB, Western blot. 
to activate the PKC- $\delta$ pathway. ${ }^{16,17}$ In the present study, we confirmed that AD198 significantly reduced cell proliferation of K9TCC and K9OSA cell lines as compared to DOX. The $\mathrm{IC}_{50}$ values of AD198, which is an important indicator for chemosensitivity of a drug, were approximately half the $\mathrm{IC}_{50}$ values for DOX in tested K9TCC and K9OSA cell lines in vitro. AD198 was the more effective chemotherapy drug as compared to its parental DOX in tested K9TCC and K9OSA cell lines in vitro. The lower effective dose of AD198 chemotherapy used in tested K9TCC and K9OSA cell lines in vitro together with the reduced cardiotoxicity detected in the rat model in vivo ${ }^{10}$ provide evidence for AD198 as a new promising chemotherapy drug that might replace DOX treatment for patients diagnosed with TCC and OSA cancers.

AD198 increased apoptosis in the K9TCC\#2-Dakota and K9OSA\#1-Zoe cells, which was confirmed by caspase-3/7 activities and is in agreement with results from previously published studies. ${ }^{11,17,42}$ AD198 activated the caspase-3/7 that in turn activated $\mathrm{PKC}-\delta$ protein in K9OSA and K9TCC cells. Edwards et $\mathrm{al}^{42}$ discovered that AD198 can also act through a PKC- $\delta$-independent mechanism in human TRAF-3 negative multiple myeloma by suppressing c-Myc expression. The different mechanisms of action of AD198 could suggest that cell origins of tumors might play an important role. It is also to be noted that DOX increased apoptosis and PKC- $\delta$ activation in K9OSA cells, but not in K9TCC cells. This finding could be due to DOX-induced caspases leading to activation of the PKC- $\delta$ pathway, which has been previously shown in Jurkat lymphoma cells. ${ }^{53}$ Studies have shown that stress-activated pathways, such as the p38 MAPK pathway, are also involved in the regulation of tumor cell apoptosis. ${ }^{54}$ Activation of the p38 MAPK pathway has been shown to induce apoptosis in human bladder cancer ${ }^{55,56}$ and OSA cells. ${ }^{57,58}$ In this study, we showed that AD198 increased phosphorylation of p38 and its downstream effectors p-CREB and p-ATF2 in K9TCC
A

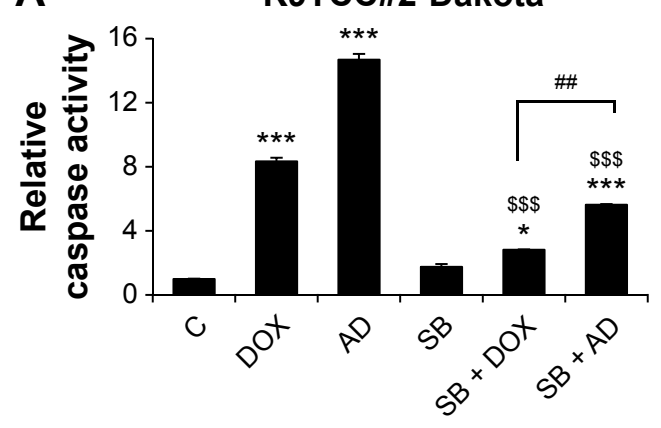

B

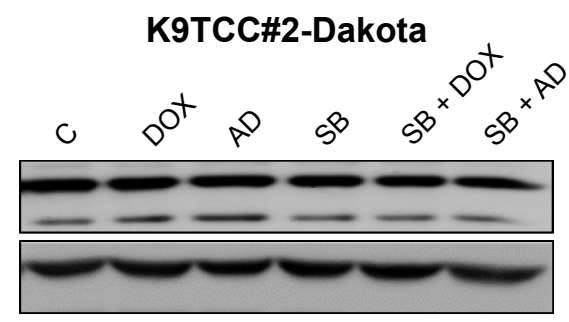

C

K9TCC\#2-Dakota

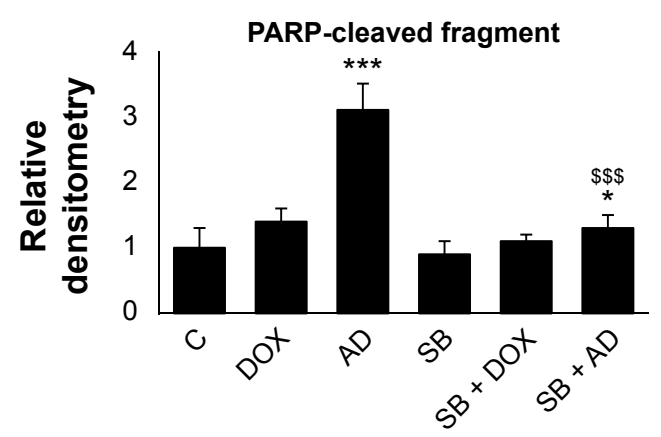

K9OSA\#1-Zoe
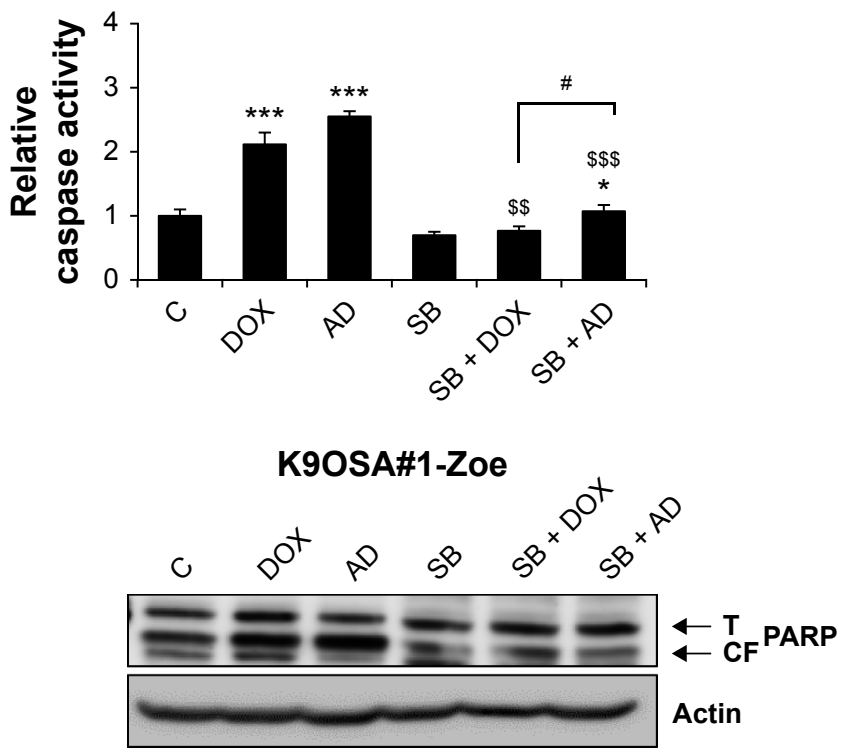

K9OSA\#1-Zoe

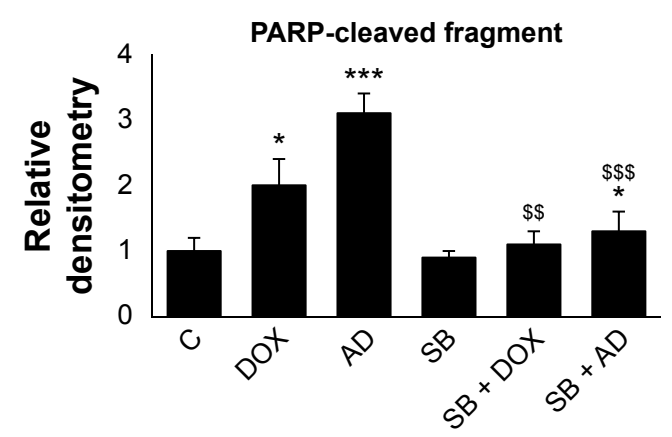

Figure 5 (Continued) 
D

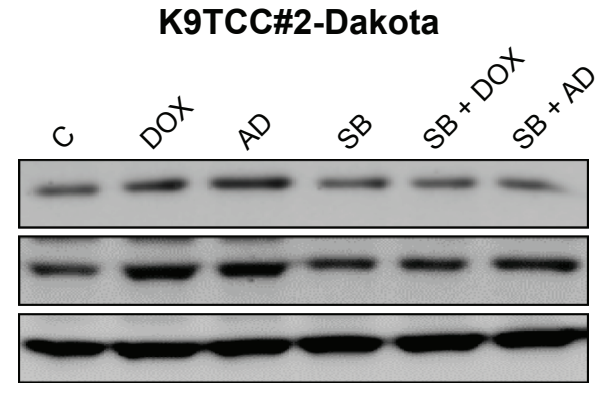

E
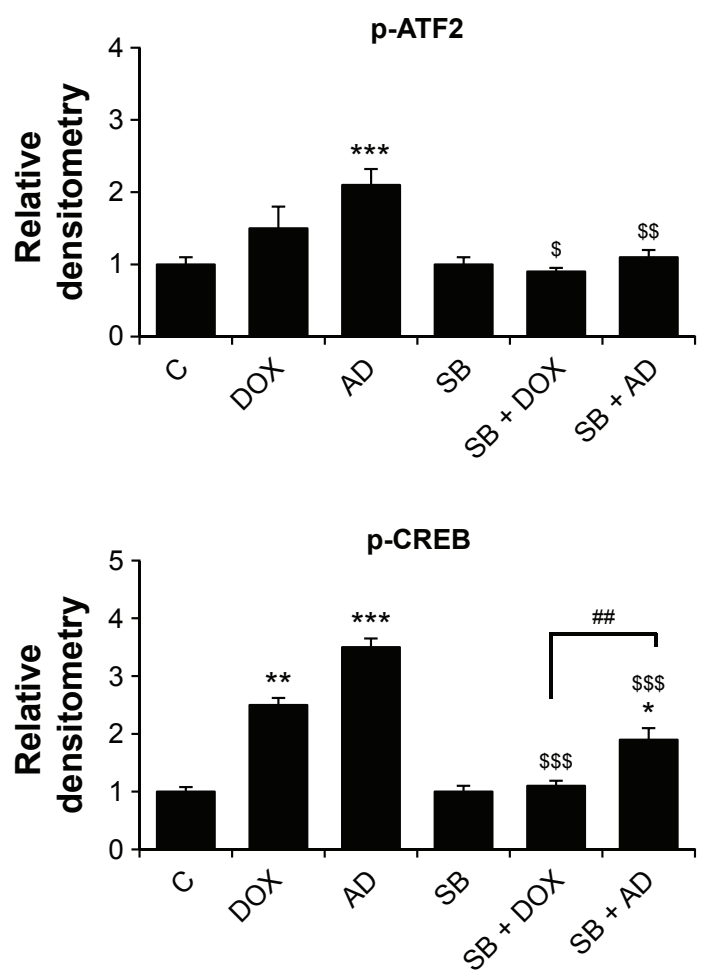

K9OSA\#1-Zoe

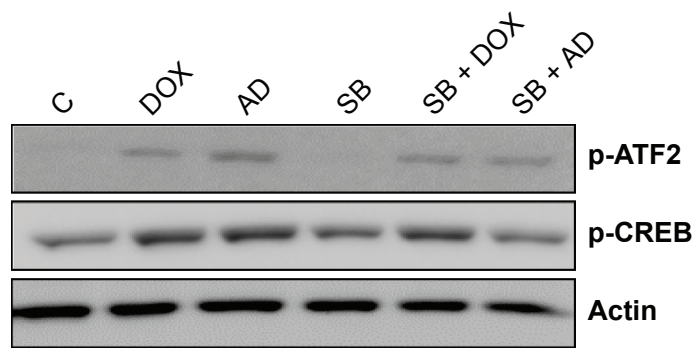

K9OSA\#1-Zoe
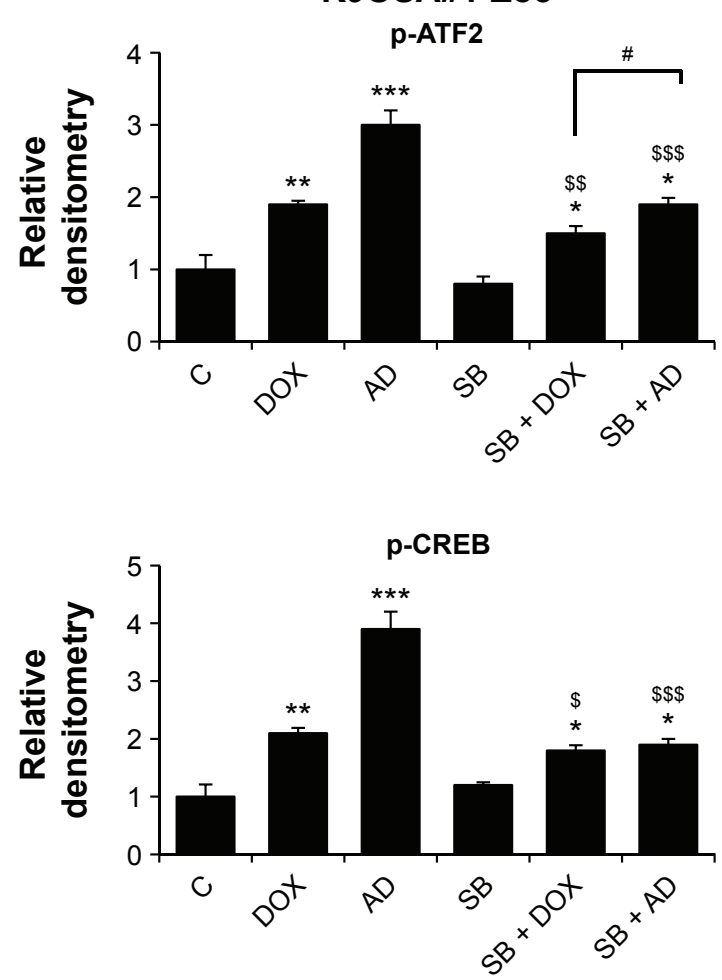

Figure 5 The inhibition of the p38 signaling pathway reduced ADI98 (AD)- and DOX-induced apoptosis in tested K9TCC and K9OSA cell lines in vitro.

Notes: (A) K9TCC\#2-Dakota and K9OSA\#I-Zoe cells were co-treated with p38 inhibitor SB (I0 $\mu \mathrm{M})$ in combination with I $\mu$ M DOX and I $\mu$ M AD for 24 hours. Caspase-3/7 activities were measured using the Caspase-Glo 3/7 luminescence assay. Relative caspase activities were normalized to control. The results are representative of three replicates in two independent experiments. Values represent mean \pm standard error $(n=6)$. Paired Student's $t$-tests comparing treatment to control $(* P<0.05$, $* * * P<0.00 I)$ SB untreated to SB treatments ( $\left.\$ \$ P<0.01,{ }^{\$ \$} \$<<0.00 I\right)$, and SB + DOX and SB + AD treatments (\#P<0.05, \#P<0.0I) were used. (B) K9TCC\#2-Dakota and K9OSA\#I-Zoe cells were co-treated with $\mathrm{P} 38$ inhibitor SB $(10 \mu \mathrm{M})$ in combination with I $\mu \mathrm{M}$ DOX and I $\mu \mathrm{M}$ AD for 24 hours. The expressions of PARP (cleaved fragment) were evaluated by WB analysis. Actin was used as loading control. The results are representative of two independent experiments. (C) Densitometry evaluation of PARP protein bands from WB analysis was done using Image software. Values represent the mean of measured densitometry of each protein's band from three replicates from two independent experiments \pm standard error $(n=6)$. Paired Student's $t$-tests were used to compare treatment to control groups $(* P<0.05$, ***P $<0.00 \mathrm{I})$ and $S B$ untreated to $S B$ treatments groups $\left({ }^{\$ P} P<0.0 \mathrm{I},{ }^{\$ \$ P}<0.00 \mathrm{I}\right)$. (D) K9TCC\#2-Dakota and K9OSA\#I-Zoe cells were co-treated with $\mathrm{P} 38$ inhibitor SB (I0 $\left.\mu \mathrm{M}\right)$ in combination with I $\mu$ M DOX and I $\mu$ M AD for 24 hours. The expressions of P-ATF2 and P-CREB were evaluated by WB analysis. Actin was used as loading control. The results are representative of two independent experiments. (E) Densitometry evaluation of p-ATF2 and p-CREB protein bands from WB analysis was done using Image software. Values represent the mean of measured densitometry of each protein's band from three replicates from two independent experiments \pm standard error ( $n=6)$. Paired Student's $t$-tests comparing treatment to control

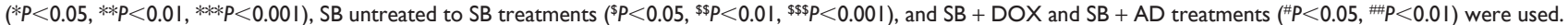
Abbreviations: AD, ADI98; ATF2, activating transcription factor 2; PARP(CF), PARP cleaved fragment; CREB, cyclic AMP response element binding protein; DOX, doxorubicin; K9OSA, canine osteosarcoma; K9TCC, canine transitional cell carcinoma; PARP, poly (ADP-ribose) polymerase; SB, SB203580; PARP(T), total PARP; WB, western blot.

and K9OSA cell lines, leading to further apoptosis. Inhibition of the p38 signaling pathway by SB203580 rescued DOX- and AD198-induced apoptosis in tested K9TCC and K9OSA cell lines, confirming the importance of p-ATF2 and $\mathrm{p}-\mathrm{CREB}$ as downstream proteins of the $\mathrm{p} 38$ signaling pathway. Our results involving p38/ATF2 and p38/CREB signaling pathways in cell apoptosis are in agreement with previously published studies. ${ }^{24,25}$

\section{Conclusion}

Our results suggest that AD198 was more effective in the inhibition of K9TCC and K9OSA cell lines as compared to 
parental compound DOX. AD198 led to apoptosis through activation of PKC- $\delta$ and p38 signaling pathways in K9TCC and K9OSA cell lines in vitro. Our in vitro results suggest that AD198 is a promising new chemotherapy drug that might be considered for clinical trials to evaluate the efficacy of AD198 as an alternative treatment option for dogs diagnosed with TCC and OSA in vivo.

\section{Acknowledgments}

We thank Dr Leonard Lothstein for providing the AD198 compound for this study. We thank Dr Alfred Legendre with assisting to identify dogs diagnosed with OSA and with obtaining OSA tumor tissue samples. We thank Dr Joseph Bartges and Ms Amanda Callens for their assistance with obtaining bladder cancer tissue samples during cystoscopy procedures of dogs. We thank the National Institutes of Health (R15-CA182850-01A1, Principal Investigator: Cekanova), the University of Tennessee Center of Excellence in Livestock Diseases and Human Health grant (R181721333; Principal Investigator: Cekanova), and Department of Small Animal Clinical Sciences (E180120; Principal Investigator: Cekanova) for supporting this research.

\section{Disclosure}

The authors report no conflicts of interest in this work.

\section{References}

1. Pommier Y, Leo E, Zhang H, Marchand C. DNA topoisomerases and their poisoning by anticancer and antibacterial drugs. Chem Biol.2010; 17(5):421-433.

2. Jamieson D, Boddy AV. Pharmacogenetics of genes across the doxorubicin pathway. Expert Opin Drug Metab Toxicol. 2011;7(10): $1201-1210$

3. Tacar O, Sriamornsak P, Dass CR. Doxorubicin: an update on anticancer molecular action, toxicity and novel drug delivery systems. $J$ Pharm Pharmacol. 2013;65(2):157-170.

4. Yagoda A. Chemotherapy of urothelial tract tumors. Cancer. 1987; 60(3 Suppl):574-585.

5. Rozzi A, Santini D, Salerno M, et al. Pegylated liposomal doxorubicin as third-line chemotherapy in patients with metastatic transitional cell carcinoma of urothelial tract: results of a phase II study. Med Oncol. 2013;30(1):407.

6. Ettinger LJ, Douglass HO Jr, Mindell ER, et al. Adjuvant adriamycin and cisplatin in newly diagnosed, nonmetastatic osteosarcoma of the extremity. J Clin Oncol. 1986;4(3):353-362.

7. Luetke A, Meyers PA, Lewis I, Juergens H. Osteosarcoma treatmentwhere do we stand? A state of the art review. Cancer Treat Rev. 2014; 40(4):523-532.

8. Hershman DL, McBride RB, Eisenberger A, Tsai WY, Grann VR, Jacobson JS. Doxorubicin, cardiac risk factors, and cardiac toxicity in elderly patients with diffuse B-cell non-Hodgkin's lymphoma. J Clin Oncol. 2008;26(19):3159-3165.

9. Volkova M, Russell R 3rd. Anthracycline cardiotoxicity: prevalence, pathogenesis and treatment. Curr Cardiol Rev. 2011;7(4):214-220.

10. Cai C, Lothstein L, Morrison RR, Hofmann PA. Protection from doxorubicin-induced cardiomyopathy using the modified anthracycline N-benzyladriamycin-14-valerate (AD 198). J Pharmacol Exp Ther. 2010;335(1):223-230.
11. Lothstein L, Savranskaya L, Barrett CM, Israel M, Sweatman TW. N-benzyladriamycin-14-valerate (AD 198) activates protein kinase C-delta holoenzyme to trigger mitochondrial depolarization and cytochrome c release independently of permeability transition pore opening and Ca2+ influx. Anticancer Drugs. 2006;17(5):495-502.

12. Traganos F, Israel M, Silber R, Seshadri R, Kirschenbaum S, Potmesil M. Effects of new $\mathrm{N}$-alkyl analogues of adriamycin on in vitro survival and cell cycle progression of L1210 cells. Cancer Res. 1985;45(12 Pt 1): 6273-6279.

13. Bao L, Haque A, Jackson K, et al. Increased expression of P-glycoprotein is associated with doxorubicin chemoresistance in the metastatic 4T1 breast cancer model. Am J Pathol. 2011;178(2):838-852.

14. Hofmann PA, Israel M, Koseki Y, et al. N-Benzyladriamycin-14valerate (AD 198): a non-cardiotoxic anthracycline that is cardioprotective through PKC-epsilon activation. J Pharmacol Exp Ther. 2007; 323(2):658-664.

15. Mellor H, Parker PJ. The extended protein kinase C superfamily. Biochem J. 1998;332(Pt 2):281-292.

16. Roaten JB, Kazanietz MG, Caloca MJ, et al. Interaction of the novel anthracycline antitumor agent N-benzyladriamycin-14-valerate with the $\mathrm{C} 1$-regulatory domain of protein kinase $\mathrm{C}$ : structural requirements, isoform specificity, and correlation with drug cytotoxicity. Mol Cancer Ther. 2002;1(7):483-492.

17. He Y, Liu J, Durrant D, et al. N-benzyladriamycin-14-valerate (AD198) induces apoptosis through protein kinase C-delta-induced phosphorylation of phospholipid scramblase 3. Cancer Res. 2005; 65(21):10016-10023.

18. Kato K, Yamanouchi D, Esbona K, et al. Caspase-mediated protein kinase C-delta cleavage is necessary for apoptosis of vascular smooth muscle cells. Am J Physiol Heart Circul Physiol. 2009;297(6): H2253-H2261.

19. Zhao M, Xia L, Chen GQ. Protein kinase $c \delta$ in apoptosis: a brief overview. Arch Immunol Ther Exp (Warsz). 2012;60(5):361-372.

20. Lee YJ, Lee DH, Cho CK, et al. HSP25 inhibits radiation-induced apoptosis through reduction of PKCdelta-mediated ROS production. Oncogene. 2005;24(23):3715-3725.

21. Fan TJ, Han LH, Cong RS, Liang J. Caspase family proteases and apoptosis. Acta Biochim Biophys Sin (Shanghai). 2005;37(11): 719-727.

22. Soldani C, Lazzè MC, Bottone MG, et al. Poly(ADP-ribose) polymerase cleavage during apoptosis: when and where? Exp Cell Res. 2001;269(2):193-201.

23. Duriez P, Shah GM. Cleavage of poly(ADP-ribose) polymerase: a sensitive parameter to study cell death. Biochem Cell Biol. 1997;75(4): 337-349.

24. Lu C, Shi Y, Wang Z, et al. Serum starvation induces H2AX phosphorylation to regulate apoptosis via 338 MAPK pathway. FEBS Lett. 2008;582(18):2703-2708.

25. Liu WH, Chou WM, Chang LS. p38 MAPK/PP2Ac $\alpha /$ TTP pathway on the connection of TNF- $\alpha$ and caspases activation on hydroquinoneinduced apoptosis. Carcinogenesis. 2013;34(4):818-827.

26. Dhawan D, Ramos-Vara JA, Stewart JC, Zheng R, Knapp DW. Canine invasive transitional cell carcinoma cell lines: in vitro tools to complement a relevant animal model of invasive urinary bladder cancer. Urol Oncol. 2009;27(3):284-292.

27. Khanna C, Lindblad-Toh K, Vail D, et al. The dog as a cancer model. Nat Biotechnol. 2006;24(9):1065-1066.

28. MacEwen EG. Spontaneous tumors in dogs and cats: models for the study of cancer biology and treatment. Cancer Metastasis Rev. 1990;9(2): $125-136$.

29. Rathore K, Alexander M, Cekanova M. Piroxicam inhibits Masitinibinduced cyclooxygenase 2 expression in oral squamous cell carcinoma cells in vitro. Transl Res. 2014;164(2):158-168.

30. Cekanova M, Uddin MJ, Bartges JW, et al. Molecular imaging of cyclooxygenase-2 in canine transitional cell carcinomas in vitro and in vivo. Cancer Prev Res (Phila). 2013;6(5):466-476.

31. Mutsaers AJ, Widmer WR, Knapp DW. Canine transitional cell carcinoma. J Vet Intern Med. 2003;17(2):136-144. 
32. Norris AM, Laing EJ, Valli VE, et al. Canine bladder and urethral tumors: a retrospective study of 115 cases (1980-1985). J Vet Intern Med. 1992;6(3):145-153.

33. Morello E, Martano M, Buracco P. Biology, diagnosis and treatment of canine appendicular osteosarcoma: similarities and differences with human osteosarcoma. Vet J. 2011;189(3):268-277.

34. LaRue SM, Withrow SJ, Powers BE, et al. Limb-sparing treatment for osteosarcoma in dogs. J Am Vet Med Assoc. 1989;195(12): 1734-1744.

35. Mayer MN, Grier CK. Palliative radiation therapy for canine osteosarcoma. Can Vet J. 2006;47(7):707-709.

36. Robat C, Burton J, Thamm D, Vail D. Retrospective evaluation of doxorubicin-piroxicam combination for the treatment of transitional cell carcinoma in dogs. J Small Anim Pract. 2013;54(2):67-74.

37. Mauldin GN, Matus RE, Withrow SJ, Patnaik AK. Canine osteosarcoma. Treatment by amputation versus amputation and adjuvant chemotherapy using doxorubicin and cisplatin. J Vet Intern Med. 1988;2(4):177-180.

38. Herman EH, Ferrans VJ, Myers CE, Van Vleet JF. Comparison of the effectiveness of (+/-)-1,2-bis(3,5-dioxopiperazinyl-1-yl)propane (ICRF-187) and N-acetylcysteine in preventing chronic doxorubicin cardiotoxicity in beagles. Cancer Res. 1985;45(1):276-281.

39. Ganapathi R, Grabowski D, Sweatman TW, Seshadri R, Israel M. N-benzyladriamycin-14-valerate versus progressively doxorubicin-resistant murine tumours: cellular pharmacology and characterisation of crossresistance in vitro and in vivo. Br J Cancer. 1989;60(6):819-826.

40. Harstrick A, Vanhoefer U, Schleucher N, et al. Activity of N-benzyladriamycin-14-valerate (AD198), a new anthracycline derivate, in multidrug resistant human ovarian and breast carcinoma cell lines. Anticancer Drugs. 1995;6(5):681-685.

41. Lothstein L, Hosey LM, Sweatman TW, Koseki Y, Dockter M, Priebe W. N-benzyladriamycin-14-valerate (AD 198)-resistant cells exhibit highly selective cross-resistance to other anthracyclines that circumvent multidrug resistance. Oncol Res. 1993;5(6-7):229-234.

42. Edwards SK, Moore CR, Liu Y, Grewal S, Covey LR, Xie P. N-benzyladriamycin-14-valerate (AD 198) exhibits potent anti-tumor activity on TRAF3-deficient mouse B lymphoma and human multiple myeloma. BMC Cancer. 2013;13:481.

43. Rathore K, Cekanova M. Animal model of naturally occurring bladder cancer: characterization of four new canine transitional cell carcinoma cell lines. BMC Cancer. 2014;14:465.

44. Cekanova M, Rathore K. Animal models and therapeutic molecular targets of cancer: utility and limitations. Drug Des Devel Ther. 2014; 8:1911-1921.

45. Lerner SP, Schoenberg MP, Sternberg CN, editors. Textbook of Bladder Cancer. Oxon, United Kingdom, CRC press; 2006.
46. Strander H. Interferons and osteosarcoma. Cytokine Growth factor Rev. 2007;18(5-6):373-380.

47. Spreafico A, Schenone S, Serchi T, et al. Antiproliferative and proapoptotic activities of new pyrazolo[3,4-d]pyrimidine derivative Src kinase inhibitors in human osteosarcoma cells. FASEB J. 2008; 22(5):1560-1571

48. Brown HK, Holen I. Anti-tumour effects of bisphosphonates - what have we learned from in vivo models? Curr Cancer Drug Targets. 2009; 9(7):807-823.

49. Di Stasi SM, Giannantoni A, Stephen RL, et al. Intravesical electromotive mitomycin $\mathrm{C}$ versus passive transport mitomycin $\mathrm{C}$ for high risk superficial bladder cancer: a prospective randomized study. J Urol. 2003;170(3):777-782.

50. Alexandroff AB, Jackson AM, O’Donnell MA, James K. BCG immunotherapy of bladder cancer: 20 years on. Lancet. 1999;353(9165): 1689-1694.

51. von der Maase H, Hansen SW, Roberts JT, et al. Gemcitabine and cisplatin versus methotrexate, vinblastine, doxorubicin, and cisplatin in advanced or metastatic bladder cancer: results of a large, randomized, multinational, multicenter, phase III study. J Clin Oncol. 2000; 18(17):3068-3077.

52. Henry CJ. Management of transitional cell carcinoma. Vet Clin North Am Small Anim Pract. 2003;33(3):597-613

53. Panaretakis T, Laane E, Pokrovskaja K, et al. Doxorubicin requires the sequential activation of caspase-2, protein kinase Cdelta, and c-Jun NH2-terminal kinase to induce apoptosis. Mol Biol Cell. 2005; 16(8):3821-3831.

54. Wada T, Penninger JM. Mitogen-activated protein kinases in apoptosis regulation. Oncogene. 2004;23(16):2838-2849

55. Zhang S, Ding D, Zhang X, Shan L, Liu Z. Maslinic acid induced apoptosis in bladder cancer cells through activating p38 MAPK signaling pathway. Mol Cell Biochem. 2014;392(1-2):281-287.

56. Wang H, Jiang D, Liu J, et al. Compound $\mathrm{K}$ induces apoptosis of bladder cancer T24 cells via reactive oxygen species-mediated p38 MAPK pathway. Cancer Biother Radiopharm. 2013;28(8):607-614.

57. Chou CT, He S, Jan CR. Paroxetine-induced apoptosis in human osteosarcoma cells: activation of p38 MAP kinase and caspase-3 pathways without involvement of $[\mathrm{Ca} 2+] \mathrm{i}$ elevation. Toxicol Appl Pharmacol. 2007;218(3):265-273.

58. Hennessy B, Mills G, Coombes K, Gonzalez-Anguelo A, Carey M, inventors; Hennessy BT, Mills GB, Coombes K, Gonzalez-Anguelo A, Carey M, assignees. Proteomic patterns of cancer prognostic and predictive signatures. United States patent US 20080108091 A1. 2008 May 8.

\section{Publish your work in this journal}

Drug Design, Development and Therapy is an international, peerreviewed open-access journal that spans the spectrum of drug design and development through to clinical applications. Clinical outcomes, patient safety, and programs for the development and effective, safe, and sustained use of medicines are a feature of the journal, which

\section{Dovepress}

has also been accepted for indexing on PubMed Central. The manuscript management system is completely online and includes a very quick and fair peer-review system, which is all easy to use. Visit http://www.dovepress.com/testimonials.php to read real quotes from published authors. 